\title{
Village Sovereignty in Dispute Resolution after Law No 6 of 2014 concerning Village
}

\author{
Ilham Yuli Isdiyanto
}

Faculty of Law, Universitas Ahmad Dahlan, Email: Ilham.isdiyanto@law.uad.ac.id

\begin{tabular}{l} 
ARTICLE INFO \\
\hline Keywords: \\
alternative dispute \\
resolution; mediation; \\
village law; village \\
sovereignty \\
How to cite: \\
Isdiyanto, I Y. Village \\
Sovereignty in Dispute \\
Resolution after Law No 6 \\
of 2014 concerning \\
Village. MEDIA \\
HUKUM, +62 274 387656 \\
(Ext. 220) \\
Article History: \\
Received: 02-09-2019 \\
Reviewed: 19-09-2019 \\
Revised: 21-12-2019 \\
Accepted: 23-19-2019 \\
\end{tabular}

\begin{abstract}
The research was conducted in order to strengthen the position of the village as a form of social control institution in solving problems that is present in the village setting which began to disappear since the independence era. A descriptive-qualitative approach with a historical-normative method is used to find the concept of the village sovereignty, obtained from studies of primary and secondary legal data. The research aims to get a historical picture as a conceptual reflection and judicial basis for developing and legitimizing the village as the place for resolving disputes among the populace. Since the monarchy until the colonial era, the village was given the authority to solve the problems of its people independently, this authority is severed after entering the independence era. The government finally began to realize the importance of village as autonomous and independent through Law No. 6 of 2014 concerning Villages and strengthened by Supreme Court Regulation; PERMA No. 1 of 2016 concerning the Mediation Process in the Court. Through the Regulation, the village head now has the authority to resolve the problems among its populace and create agreements regarding it. Hence, support from the government is needed to the respective village heads and the chosen delegates through regulation and mediation training.
\end{abstract}

DOI: 10.18196/jmh.20190136

Copyright (02019 MEDIA HUKUM. All rights reserved.

\section{Introduction}

After the legalization of Law No. 6 of 2014 concerning Villages, discussions about villages became more attractive to many people. The existence of the village, which previously limited to demography administration, has become increasingly widespread supported by the existence of quite large Village Funds directly sourced from the APBN (State Budget) for capital development and village empowerment. Discussions and studies related to the village are interesting because it has a solid history in Indonesia both before the era of the Republic of Indonesia and in the process of independence. Based on research conducted by Hamid S. Attamimi, it was said that 
the "Village Republic" was material and reflection in the formation of the "Republic of Indonesia." ${ }^{1}$

The term "Village Republic" emphasizes the existence of the village as the smallest form of territory with an independent government system with a legal order and an autonomous justice system. Village position has emerged since a long time ago, even since the Majapahit era; Village had the autonomy right to uphold its legal order as long it did not disturb the kingdom interest. ${ }^{2}$ Village sovereignty related to judicial powers even existed until the VOC era, known as Village Court (Rechtpraak Village).

The reverse phenomenon occurred during the start of the Republic of Indonesia era, where local law was not in accordance with the spirit of modernity or the renewal times. By using the West as a measure of modernity, there is "anxiety" in seeing and understanding the law itself. One of them is legal homogeneity by implementing legal unity nationally to create legal certainty (supremacism of law). One exponent, in this case, is Mochtar Kusumaatmadja, who tried to legitimize the concept of legal unity by quoting the understanding of Pancasila with the second principle as a base of unity ${ }^{3}$.

These ideas related to the unity of law will undoubtedly grind the existence of local laws that are not legitimate by the State. Thus, they directly participate in eliminating the forms of Village Courts in many areas. The idea of legal unity is supported and validated by the government through Emergency Law No. 1 of 1951 concerning Temporary Actions to Organize Power Unity and Civil Court.

After eliminating the existence of the Village Court, the independent and autonomous village sovereignty turned into a village that depends on the Government, which certainly adding the Government burden. As if not enough to do uniformity in the legal field, the Government then made a fatal mistake by implementing Law No. 5 of 1979 concerning the Village Government. The term Desa (Java) is getting rid of other names such as Gampong (Aceh), Nagari/Kampuang (West Sumatra), Huta/Nagori (Tapanuli), Temukung (NTB), Banjar (Bali), Wanua (North Sulawesi), and Tiyuh/Pekon (Lampung). Village function as an independent and autonomous government has shifted into an administrative capacity as an extension of the Government. Referring to the provisions of Article 10 jo Article 11 jo Article 12 jo Article 13 of this law, it is difficult to see clear boundaries between the Rights, Authority, and Obligations of the Village Head. It is even more confusing to see in more details that the provisions of Article 10 Paragraph 1 of this law which states one of the implementations of public government is by fostering peace and order (not resolving conflict or citizen's problem) which based on the prevailing rules and regulations, but there are no other laws that regulate the meaning of fostering order.

The government then began to realize its mistakes by controlling the village centrally, making its burden too heavy, both in the economic and legal area. In the legal sector, the centralized justice-system increased number of cases. The latest data showed that

1 Attamimi, A. H. S. (2018) Peranan Keputusan Presiden Republik Indonesia dalam Penyelenggaraan Pemerintahan Negara. Jakarta: Universitas Indonesia, p.104.

2 Boechari. (1975). Jayapatra Sekelumit Tentang Pelaksanaan Hukum dalam Masyarakat Jawa Kuno, in Simposium Sejarah Hukum. Bandung: BPHN Kemenkuham, p.88.

3 Kusumaatmadja, M. (2006). Konsep-Konsep Hukum dalam Pembangunan; Kumpulan Karya Tulisan Prof. Dr. Mochtar Kusumaatmadja, S.H., LL.M, ed. (Ed.). Salman, O \& Damian, E. Bandung: PT Alumni,p.10. 
throughout the first semester of 2017, the Supreme Court received 8,397 cases ${ }^{4}$. Strangely, the Government is trying to make new legal concepts by adopting restorative justice and requiring mediation efforts, which had all been well carried out by the Village. Since the village lost the authority of social control through an autonomous justice system, the Government is now facing piled-up cases becoming extraordinary burden for the State.

The momentum of reformation era in 1998 was also considered to be an entry point for strengthening local nuances in each region ${ }^{5}$ which then strengthened by Law No. 6 of 2014 concerning Villages. Through the law, Village is reassigned with a lot of authority and freedom to regulate its household autonomously under the guidance of the Regional Government and the Central Government. The most significant homework is whether Law No. 6 of 2014 concerning this Village can accommodate the needs of the Village's sovereignty like before. Based on that, it is necessary to know how far Law No. 6 of 2014 concerning Villages accommodates the Village to regain its independence, especially in the judicial field.

Therefore, based of the description, the research has purposes to answer the question is; how are the dynamics and dialectics of village sovereignty in Indonesia? and how does Law No. 6 of 2014 concerning Villages accommodate the existence of village sovereignty in alternative dispute resolutions?

\section{Method}

The research uses a descriptive-qualitative approach where each data processing is explained in details to get a clear picture of the direction and map of the study in order to find the core to obtain a comprehensive map of the study. The approach is combined between historical and normative methods, which the way of looking at the welfare of legal developments and their implementation becomes a vital entity of a whole process for seeing problems and achievements in the present. The historical perspective on law development and its application becomes an essential entity to view the issues and results in the present.

The data analyzed in the research are secondary in the form of primary legal data and secondary legal data. The analysis result was not only a conclusion without meaning, but according to normative legal research, it is also able to provide a prescriptive side of suggestions to implement.

\section{Analysis and Results}

\subsection{Definition of Village Sovereignty}

The term village sovereignty in this research refers to the concept of "The Village Republic," which is the base in designing the "Republic of Indonesia" by Soepomo. According to Soepomo, as an expert in the field of Adat Law, Village Republic became the design foundation of the Republic of Indonesia due to the shared ideals of its

\footnotetext{
4 (https://kepaniteraan.mahkamahagung.go.id/index.php/kegiatan/1444-semester-pertama-2017-mamenerima-8-397-perkara)

5 Fitriati. (2017). "Karakteristik Penyelesaian Tindak Pidana Secara Informal Melalui Peradilan Adat". Media Hukum, 24(2), 164-171. https:/ / doi.org/10.18196/jmh.2017.0092.164-171
} 
formation, namely a model adapted to the social culture of Indonesian people and the spirit of the era ${ }^{6}$. Using the word "republic" is very politic. Furthermore, the crucial aspect of the village is a form of leadership and power that comes from the people.

The Village Republic then referred to as the original government in Indonesia, reinforced by Ateng Syafrudin and Suprin Na'a's opinions ${ }^{7}$; first, from van Vollenhoven's notes, it was known that the Village Republic already existed before the Dutch entered Indonesia, even with a democratic system that emphasized people's welfare and autonomy based on its local culture. The conception of democracy in Indonesia is far more advanced than the Western concept of democracy, which is limited to the political system. As spoken by Moh. Hatta, democracy in rural Indonesia is not only related to practical political aspects, but economic democracy ${ }^{8}$. Secondly, Dutch maintained the continuity of village autonomy based on Adat Law. Third, the integralist conception carried out by Soepomo was based on the philosophy of manungaling kawula gusti, meaning the unification of people and their leaders to become an ideal nation in Indonesia. The concept is from the culture in the countryside with its communal awareness

\subsection{Village Regulation in Indonesia}

The village, as a legal alliance in the dynamic and dialectic journey, has experienced extraordinary fluctuations. Monarchy era made the village independent by administrative and law, but land ownership rights became the anggaduh rights as happened in the Majapahit period until the Yogyakarta Sultanate. In the Majapahit age, according to the Kutaramanawadharmasastra, the land ownership was owned by the kingdom.

Entering the Colonial period, the Village also did not lose the attention. The forerunner regulation of the village was in "Regeeringsreglement" 1854 concerning Regions and Villages. Article 71 (Article 128.IS) confirmed the position of the village. First, the village in the regulation was called "inlandsche gemeenten" for legalizing regional head (resident) to choose his head and local government. Second, the village head was allowed to regulate its household by observing the regulations that came from the governor-general or the regional leader (resident) ${ }^{9}$. After that, other rules emerged, such as the De Inlandsche Gemeente Ordonantie in 1906, which was announced in Inlandsche Staatsblads No. 83 of 1906 and intended to regulate management affairs and the household interests of indigenous rural communities in the Java and Madura regions ${ }^{10}$. After that the rules about Village in the Colonial era continued to grow out of Java and Madura but broadly remained the same as the Village as an autonomous legal alliance to manage their own households based on Adat and culture under the supervision and control of regional head (resident) as an extension of the Netherland Indies government.

6 Attamimi, A. H. S. (2018). Peranan Keputusan Presiden Republik Indonesia Dalam Penyelenggaraan Pemerintahan Negara. Jakarta: Universitas Indonesia, p.103.

7 Huda, N. (2015). Hukum Pemerintahan Desa. Bandung: Setara Press. p.2-3.

8 Hatta, M. (1966). Demokrasi Kita. Djakarta: PT Pusaka Antara. p. 24.

9 Eko, S. (2005). Mencari Model Pemerintahan dan Otonomi Desa. In R Widodo Triputro dan Supardal (Ed.), Pembaharuan Otonomi Daerah. Yogyakarta: Program Studi Ilmu Pemerintahan STPMD “APMD” dan APMD Press Yogyakarta. p.241

10 Wignjosoebroto, S. (2014). Desentralisasi Dalam Tata Pemerintahan Kolonial Hindia-Belanda: Kebijakan Dan Upaya Sepanjang Babak Akhir Kekuasaan Kolonial Di Indonesia 1900-1940. Malang: Banyumedia. p.43-44. 
During the Japanese colonialism, the administrative field also received serious attention. They formed the administrative unit until the smallest population of the Rukun Tetangga (Tonarigumi) ${ }^{11}$. Regarding administrative rights, the position of villages in Java and Madura were not in Law No. 34 of 1942, except in Sumatra written in Article 1 Sjihososjiki-rei (Law Article concerning the regulation of Judges and the Court) ${ }^{12}$.

At the time of the independence era, Village as an equitable society is still approved as written in Principle No. 18 of the 1945 Constitution of The Republic of Indonesia, where the government recognized the origin of the area as a privilege right. But this good first step is not followed by the next steps. The uniformity of the village existence began to appear after the legalizing of Law No. 22 of 1948 concerning the Establishment of Basic Rules Regarding Self-Government in the Regions that have the right to regulate and manage their own houses by calling the legal society as a "Desa" like in Java. This appellation is the beginning of uniformity of the local government in Indonesia, which in turn raised the problem of rules to accommodate diversity ${ }^{13}$. This step was further emphasized after the New Order ruling by issuing Law No. 5 of 1979 concerning the Village Government. The term Desa in this law article is decisive of brutal homogenization from the central government towards the village; moreover, the position of autonomous and independent community is trimmed under central government control through the sub-district head.

A new round took place after the 1998 reformation, where fresh air towards the Village re-emerged after the enactment of Law No. 22 of 1999 concerning Regional Government, which no longer positioned the Village as an administrative area under sub-district head, rather a legal society unit that lives autonomously. The law turns out to be only aging no more than five years and then replaced with Law No. 32 of 2004 concerning the Regional Government, but the law also does not have a significant effect on village transformation. Later, this law also replaced by Law No. 23 of 2014 concerning the Regional Government.

Finally, in 2014, the Government began to seriously empower the village and place it as an independent and autonomous legal alliance by issuing Law No. 6 of 2014 concerning Villages. At this point, there is a question of whether the latest regulation can fill the lack of the previous rules in returning the village dignity.

\subsection{Dispute Resolution in Indonesia}

Law enforcement is an essential aspect in society, and state life, stability, and social control start from here. A law - however good - will be of no use if it is unable to create order and become social control. Since the monarchy era, social control through law enforcement in the judiciary has become a serious thing. In the Himad Inscription, Gajah Mada mentioned that besides being Patih, he also often acted as a judge called $\mathrm{Pu} \mathrm{Mada}$, who had succeeded in resolving various cases which were later recorded in a

11 Matanasi, P. (2017). Asal-Usul Rukun Tetangga. Retrieved from tirto website: https://tirto.id/asalusul-rukun-tetangga-cBhG.

12 Mertokusumo, S. (2011). Sejarah Peradilan dan Perundang-Undangannya Di Indonesia Sejak 1942 dan Apakah Kemanfaatannya Bagi Kita Bangsa Indonesia. Yogyakarta: Universitas Atma Jaya Yogyakarta. p.31.

13 Eko, S. (2005). Mencari Model Pemerintahan dan Otonomi Desa in R Widodo Triputro dan Supardal (Ed.), Pembaharuan Otonomi Daerah. Yogyakarta: Program Studi Ilmu Pemerintahan STPMD “APMD” dan APMD Press Yogyakarta. p. 242. 
jurisprudence book commonly called Kitab Gajah Mada. Muh.Yamin also confirmed in his book "Majapahit State Administration" ${ }^{14 "}$.

Still, the form of the judiciary has also been decentralized between the royal court and regional court managed by the village. Unfortunately, the form and dynamics relationship between them is not developed further when Indonesia independence, instead adopted the legal concepts from the Colonial era. Through the independence era, the form of the State had become the Unitary Republic of Indonesia. Unfortunately, justice system does not indicate a unity because of federal states, which consist of states where each region is allowed to regulate its judiciary ${ }^{15}$.

The form of the Republic of Indonesia, which is based on unity, applies different principles on the basis of the legitimacy of 'unity,' and then the framework of the national justice system is centralized under the Supreme Court. Emergency Law No. 1 of 1951 concerning Temporary Actions to Organize Power Unity and Civil Court is the first step towards the centralization of Indonesia's national justice system. Through this law in Article 1, the forms of self-governing courts (Zelfbestuursrechtspraak) and Customary courts were abolished (Inheemse rechtspraak in rechtstreeksbestuurd gebied).

Slow but sure, the government then eroded judicial authorities in the regions as well as in villages based on Adat and local culture. Through the Supreme Court's jurisdiction, the need for achieving justice is deemed sufficient and guarantees more legal certainty in accordance with the national legal uniformity program. Pronouncing Indonesia, as state law, has an impact on understanding law so that a competent judicial institution becomes a necessity.

The monopoly of the judiciary by the Supreme Court then became a burden towards seeking justice in society, a higher burden of cases, and a narrower space of justice became the reason why the judicial institution's monopoly needs to be reviewed. Now, the goal of seeking justice in the country has turned into a pragmatic goal to seek victory. The terms fair and unfair are transformed into win and lose.

Efforts for a peaceful settlement based on configuring local values and local norms that managed and developed by the local judiciary institutions then begin to fade and disappear. Of course, this is a problem when "peace" is the best accommodation of justice and becoming habit ${ }^{16}$. This problem is a severe problem that must be solved, worsened by the domino effect from a higher burden when a case is not handled by a judge who is an expert in his field ${ }^{17}$.

\subsection{Dynamics and Dialectics Village in Indonesia}

The Concept of "Desa Mawa Cara, Negara Mawa Tata" is one of the Javanese advice, which is very meaningful, especially as a manifesto of village independence, government system, including the settlement of village communities. According to Sutoro Eko as quoted by Udiyo Basuki, "Desa Mawa Cara" produced the phrase "village

14 Yamin, M. (1962). Tatanegara Madjapahit (Parwa III). Djakarta: Jajasan Prapantja. p. 242.

15 Mertokusumo, S. (2011). Sejarah Peradilan dan Perundang-Undangannya Di Indonesia Sejak 1942 dan Apakah Kemanfaatannya Bagi Kita Bangsa Indonesia. Yogyakarta: Universitas Atma Jaya Yogyakarta. p.125-126.

16 Hadikusuma, H. (1981). Hukum Tatanegara Adat. Jakarta: Alumni. p. 134.

17 Mahkamah Agung Republik Indonesia. (2010). Cetak Biru Pembaharuan Pengadian 2010-2035. Retrieved from https://www.mahkamahagung.go.id/media/198 p. 8 
way" which means the village has its ways, local wisdom, and local initiatives, while "Negara Mawa Tata" also means the state has its way ${ }^{18}$.

The village as an autonomous entity alliance since the monarchy era has been highly developed with wisdom and Adat that form their social institutions independently. In the period of Majapahit kingdom, the village position was very independent even has the right to implement its legal system in a sovereign manner ${ }^{19}$.

Different from the colonial era, the village position de jure was recognized and autonomous, but de facto the village position was still a colonial object of Netherland Indies government to exploit human resources and natural resources in its colonies.

Article 71 Regeeringsreglement and Article 128 Indische-statsregeling and Japanese Government Regulation No. 1 In 1942 and the rules of Osamu Seirei No. 27 of $1942^{20}$ Acknowledged the village's existence and autonomy, especially the village as a small republic that independent and had its system of government and law. However, in de facto, the village's existence could not be separated from the system of bureaucracy and colonial economy so that the village remained as the object of colonialism.

Entering the independence era, where the colonial state changed into the Republic of Indonesia, there were significant changes in the configuration of the village position, both in legal, political, and economic fields. At the beginning of the independence era, the Republic of Indonesia, which conceptualized by Soepomo based on a reflection on the building of the "Village Republic." ${ }^{21}$ The meaning of the Village Republic itself implies a form of village capacity in terms of independently managing legal, political, and economic fields. So, reflecting from the Village Republic as the building foundation of the Republic of Indonesia at least can be the goal of a country; that is independent and autonomous.

However, after Indonesia gained its independence, the position and existence of the village were more amputated. Startd from ratifying Emergency Law No. 1 of 1951 concerning Temporary Actions to Organize Power Unity and Civil Court, where Village Courts, Customary Courts, Private Courts, and other forms of local justice were abolished into State or centralized Courts. After the Law was issued thus as social control, the village position became weaker because village institutions were no longer a social problem solver. At those time there's a period of Suhardiman S. called "village negotiation". It was based on 2 (two) regulatory instruments, namely Law No. 13 of

18 Basuki, U. (2017). "Desa Mawa Cara Negara Mawa Tata : Dinamika Pengaturan Desa Dalam Sistem". Al Mazahib, 5, 321-344. Retrieved from http://ejournal.uinsuka.ac.id/syariah/almazahib/article/view/1424

19 Raharjo, S. (2011). Peradaban Jawa: Dari Mataram Kuno sampai Majapahit Akhir (Cet II). Jakarta: Komunitas Bambu. p.39. The village since ancient times is an organic legal community, their existence independently existed before the emergence of big kingdoms. Thus, the village will not change even though a greater alliance of territory such as alliance between villages or even the kingdom changes according to the era of its ruler. Even according to Soetardjo Kartohadikoesoemo as quoted by Irawan Djoko N. (2009) said that the village alliance with its government system is permanent and in control of its territory.

20 Syamsu, S. (2008). "Memahami Perkembangan Desa di Indonesia". Jurnal Government Ilmu Pemerintahan, I(I).

21 Attamimi, A. H. S. (1990). Peranan Keputusan Presiden Republik Indonesia Dalam Penyelenggaraan Pemerintahan Negara. Universitas Indonesia. p.120 
1946 concerning the Elimination of Desa Perdikan and Law No. 14 of 1946 concerning Making Changes in the Year 1907 No. 212 Regarding the Election of Village Heads ${ }^{22}$.

Law No. 14 of 1946 concerning Establishing Amendments in the Staatsblad 1907 No. 212 Regarding the Election of the Village Head, also regulates the right to choose the village head directly by the society with minimum age 18 years and over or married. This law seems to want to restore the village sovereignty with its direct election system. But again, the State is homogenizing and oversimplifies this issue. The form of village head succession certainly has many various kinds, as well as in the case of adult perspectives and the position of men and women in their status. Therefore, the village's efforts to regulate voters are also a form of village statement as a subordination of the State.

However, before the issuing of Law No. 13 of 1946 concerning the Elimination of Desa Perdikan and Law No. 14 of 1946 concerning Making Changes in the Year 1907 No. 212 Regarding the Election of Village Heads, which referred as the starting point of state cooptation to the villages, in the following year through the Law of the Republic of Indonesia Number 22 of 1948 concerning Establishment of Basic Rules Regarding SelfGovernment in Regions Entitled to Manage and Manage their Own Housings into Embryos this. Article 1 stated that the Republic of Indonesia is composed of 3 levels; the Province, Regency, and Village. The village is still given free space to regulate and manage its household even the State recognizes its rights based on the origins obtained from before Independence Day. However, the article places the village in the subordinate hierarchy of the state government system.

An understanding of the village also appeared in Law No. 18 of 1965 concerning the Principles of Regional Government, where villages or regions that were on the same level were legal society units with a principal who had the right to regulate and manage their own homes. A similar understanding also exists in Law Number 19 of 1965 concerning Desa Praja as a Transitional Form to Accelerate the Formation of Level III Regions throughout the Republic of Indonesia. In both laws, the village seems to have been given more rights in terms of autonomy and regulation, but to put it mildly, there has been a form of "uniformity" where the word "village" or "desa praja" has been used by default.

In the next regulations mainly related to the regional government system, the village concept is not so much discussed. As in Article 88 of Law Number 5, Year 1974 concerning the Principles of Government in the Regions stated that separate laws establish the regulation of the village government. This village regulation requires specificity is not a new thing; the strategic position of the village as the root since the Netherland Indies era has become one of the main concerns. On the other hand, the forms of diversity villages can not equated in one same perception even though through Law Number 18 of 1965 concerning the Principles of Regional Government and Law Number 19 of 1965 concerning Desa Praja As Transitional Forms for Speeding Up The establishment of Level III Regions throughout the Republic of Indonesia has been carried out in a subtle but massive manner.

Law No. 5 of 1975 concerning Village Government being an additional tool to uniformity the village. In Article 1 (1) stated:

22 Syamsu, S. (2008). "Memahami Perkembangan Desa di Indonesia". Jurnal Government Ilmu Pemerintahan, I(I). 
"Village is an area occupied by a number of residents as a social unit including a legal society unit that has the lowest government organization directly under the sub-district head and has the right to hold his household in the bond of the Unitary State of Republic of Indonesia."

In the article, it is clearly stated that the village is part of subordinate system of the central government; thus, in this case, it negates the status of an independent and autonomous village, as stated in the previous law. Law Number 5 of 1975 concerning Government is the culmination of the State's domination of village autonomy, it places the village not as an autonomous region with the concept of "mawa cara" but as an extension of the central bureaucratic system to the regions and more in administrative authority.

Compared to the reform era, the village rights and authorities are getting fresh air. The centralized pattern of the New Order under Soeharto did put the village as an extension of the government bureaucracy in the lower regions, so it was more active in carrying out administrative tasks, therefore one of the spirits of reform was autonomy in the area where the village also received an important role in obtaining its autonomy right. Post-reform, Law No. 22 of 1999 emerged concerning Regional Government that accommodated rights based on origins, which had almost disappeared due to the efforts to erase the images of strong villages from the central government.

In 2004 a new regulation appeared to regulate the relationship between the central and the regions including the village, through Law Number 32 of 2004 concerning Regional Government which in the clause of Article 1 Paragraph (12) states:

"A village or another name hereinafter referred to as a village, is a legal society unit that has regional boundaries that authorized to regulate and manage the needs of the local people, based on local origins and Adat that are recognized and respected in the Republic of Indonesia."

However in this law, the village can be transformed into an urban village (kelurahan) through a local regulation (PERDA), and the status of the urban village is better than the village status because the urban village carries out decentralization function due to the delegation of authority from the mayor.

Referring to Article 18 Paragraph (1) of the 1945 Constitution which states "the Republic of Indonesia is divided into provincial regions, and the provincial regions are divided into regencies and cities, each province, district and city has a regional government, regulated by law " then the relationship between the central and regional governments is horizontal because the term "divided " is an authority which is attributed by the 1945 Constitution.

Fresh air towards the efforts to village autonomy began to re-appear through Law No. 6 of 2014 concerning Villages. This law is considered as the starting point to start putting the village in a strategic position in the state system. It is in the clause of Article 19, which mention the village authority as follows:

a. Authority based on origin rights;

b. A local authority based on village-scale;

c. Authority assigned by the Government, Provincial Government, or Regency / City Government; and 
d. Other authorities assigned by the Government, the Provincial Regional Government, or Regency / City Regional Government in accordance with statutory clauses

Powers given to the village through Law No. 6 of 2014 concerning Village represent autonomy. Especially in the clause of Article 20, it clearly states that the authority is based on origin rights, and local authorities are arranged and managed by the village self. It is an effort to recognize the village sovereignty, which is limited by its territory, where the village is no longer reduced to a concept but starts to receive legal support and support systems by the State. Origin rights or also called "primordial rights", "traditional rights" are rights that had been embedded and existed before the era of the Republic of Indonesia, then it was the state's obligation to respect and legitimize them ${ }^{23}$.

\subsection{The Urgency of the Village Authority in Alternative dispute resolution}

Formal conflict resolution through legal court institutions often faces problems, especially in terms of gaining public trust. At the very least, there are three fundamental issues in the world of justice, namely the handling of slow cases, difficulties in accessing court information, the integrity of the judicial apparatus, especially judges ${ }^{24}$.

The first issue related to the handling of the judiciary, which is slow is contrary to Article 4, Paragraph 2 of Law No. 48 of 2009 concerning Judicial Power, which states:

"Courts help justice seekers and try to overcome all obstacles and obstacles to achieving a simple, fast, and low-cost trial."

The next problem is the difficulty of accessing court information so that the parties must passively wait for news from the court. It is undoubtedly related to the lack of maximum use of integrated information technology. Even though the justice system has now used the e-court system, which is a service for Registered Users for Online Case Registration, Getting Online Estimated Case Fees, Online Payments, and Summons made with electronic channels ${ }^{25}$. However, the use of an automated information system is indeed implemented in an evaluation of the effectiveness of its use.

Besides that, among the two problems above, the most important is the integrity of the court apparatus, especially judges. In February 2017, Legal and Monitoring Division of Indonesia Corruption Watch (ICW) Aradila Caesar said that there were at least 20 more judges who were charged with corruption cases related to bribery in handling cases ${ }^{26}$. The lack of integrity of judges has actually become a long-standing issue in Indonesia, even in 1999, the Institute for the Study and Advocacy of Judicial Independence in Indonesia has provided recommendations as a core of the field of reform in the Judicial Power Sector. Second, restore the essential functions of the judicial power to realize justice and legal certainty; Third, carry out checks and balances functions for other state institutions; Fourth, to encourage and facilitate and uphold the principles of a

\footnotetext{
23 Alia, M. I. (2017). Jaminan Konstitusionalitas Hak Asal Usul Masyarakat Hukum Adat di Sumatera Barat. Lex Journal: Kajian Hukum \& Keadilan, 1(2), 1-25. https:/ / doi.org/10.25139/lex.v1i2.550

$24 \quad$ http://www.pembaruanperadilan.net/v2/2017/02/begini-cara-ma-mengatasi-tiga-hambatanperadilan/).

$25 \quad$ (http:/ / ecourt.mahkamahagung.go.id/)

26(http:/ / nasional.sindonews.com/read/1179157/13/icw-sudah-20-lebih-hakim-dijerat-kasus-korupsi1486884585)
} 
democratic law in order to realize people's sovereignty; Fifth, protect human dignity in the most concrete form ${ }^{27}$.

Based on these discussions, the issue of formal justice institutions in Indonesia is not only within the institutional domain but also in the matter of the integrity of the apparatus so that it becomes a stimulus for the weak public trust in the judiciary itself. This issue arises because the judiciary is an institution that is primarily used to seek and fight for justice, but if the society does not trust the judiciary again, it should be a concern by finding alternative solutions that better reflect the sense of justice of the community.

Alternative resolutions developed by the Government are currently fixed on rigid formalistic institutions, such as Arbitrase institutions based on Law No. 30 of 1999 concerning Arbitration and Alternative Dispute Settlement and through the certification of Independent Mediators based on Supreme Court Regulation PERMA No. 1 of 2016 concerning Procedure for Mediation in the Court has not been genuinely optimal and is capable of significantly reducing the burden of cases.

So far, the Government rarely sees village potential as one of the bases for solving social problems. Based on data downloaded from the website of the 2014 Central Statistics Agency, the total number of villages in Indonesia reached 83,931 villages ${ }^{28}$. If a large number of villages are properly utilized in settling cases, they will be able to reduce the burden of cases that are so large and the local wisdom approach to accommodate the values of social justice rather than formal justice.

Supposedly, learning from the history of the kingdom and the era of colonialism where the village was given authority and autonomy in the field of jurisdiction has been able to become an effective and efficient system in handling cases so as to reduce the overall burden on the State. The existence of the concept of the Village Republic, which was reduced in the era of the Republic of Indonesia, has become a serious problem, including case handling. In fact, in terms of handling cases, informal institutions now identified with "win" and "lose" not "fair" and "unfair" so that when sad if the concept of the word justice itself comes from the basic word "fair."

\subsection{Village Sovereignty in Alternative Dispute Resolution after Enactment of Law No. 6 of 2014 Concerning Village}

The village paradigm developed not only as an extension of the central government bureaucracy in the field of administration began to be felt in Law No. 6 of 2014 concerning Villages, especially the provisions of Article 19, one of the exciting authorities regarding the right of the origin.

This article is the entrance to the direction of the actual village dignity but still tendentious on the concept of indigenous peoples rather than the village in general. The village authority in general in the origin rights is still accommodated in terms of institutions and village society agreements.

27 Wantu, F.M. (2013). "Kendala hakim dalam menciptakan kepastian hukum, keadilan, dan kemanfaatan di peradilan perdata ". Mimbar Hukum - Fakultas Hukum Universitas Gadjah Mada, 25(2), 205-218.

28 Badan Pusat Statistik. (n.d.). Jumlah Desa/Kelurahan Menurut Provinsi dan Topografi Wilayah, 2003 2018. Retrieved from www.bps.go.id website: https://www.bps.go.id/linkTableDinamis/view/id/907 
Village authority in the judicial sector is a historical necessity, but this authority is unilaterally taken by the Government and becomes a matter of Government so that it is not given to the regions or villages. It is necessary to underline that judicial authority becomes very important in the village, especially in raising its sovereignty due to several reasons. First, the village is the most directly related to the interests of the society, so that the authority in the judiciary will make the village easier to control and courting the lives of its citizens. Second, the village has organic values or morality that are always developing within its territory. Therefore, these organic values and morality need to be accommodated and actualized through village existence in the judicial field. Third, the village has a significant role in the administration of order, peace, and protection of the region and its citizens so that the authority in the judicial sector will help the village to maximize the implementation of the law, peace, and direct protection.

More specifically, in the provisions of Article 26 Paragraph 4 letter k, the village head obliges to resolve social conflicts in the village. This provision is not in the explanation so it becomes summed up on it means to settle village society conflicts.

The word "finishing" is an "active" rather than "passive" word, so the head is obliged to resolve village society conflicts here, then the village head resolves disputes within the village society. The next problem is, how do the village heads and technicalities be addressed in determining conflicts in the village?

These issues are indeed a problem in terms of applying the authority of the village head in resolving society problem conflicts in the village considering that in the Article 10 Paragraph 1 Letter d of Law No. 24 of 2014 concerning the Regional Government clearly states that the affairs of the "justice" sector constitute absolute authority from the Government, so what form of settlement the village government can offer. This problem is indeed not easy because it is not only about typical villages but also with traditional villages that have problem-solving institutions or social conflicts that have existed to this day. It will be a question of how the legitimacy of the conflict resolution institutions (especially those that have developed since time immemorial) while the problem of the judiciary is absolute government affairs.

Basically, with the existence of the Village Law No. 6 of 2014 concerning Villages gives legitimacy to the use or implementation of customary law as long as the enactment does not threaten the sovereignty and integrity of the State and the number of customary law in substance does not contend with the provisions of the legislation. Although it is somewhat confusing regarding the withdrawal of judicial authority, at least the position of customary law has a place in the national legal system. It's just that the number of traditional villages in Indonesia is very few, majorly a traditional village.

If the traditional villages have institutionalized sovereignty, then the next is the conventional village position, which is given the authority to resolve conflicts but is not regulated in institutionalization. Because it is not regulated institutionally or in terms of the program, it is best to place the position of the village as an alternative dispute resolution.

Referring to the clause of Article 1, Paragraph 10 of Law No. 30 of 1999 concerning Arbitration and Alternative dispute resolution states:

"Alternative dispute resolution is an institution to alternative dispute resolution or difference opinion through a procedure which agreed upon by the parties, namely an 
out-of-court settlement by consultation, negotiation, mediation, conciliation, or expert judgment."

In the clause of Article 6, paragraph 1 stated that alternative dispute resolution is the waiver of a formal legal settlement in litigation (court) so that the consequences of this clause make the outcome of settlement through alternative dispute resolution institutions is legally recognized. However, the provision in Law No. 30 of 1999 did not clearly state what kind of those institutions; thus, in this case, there was no explicit mention of the village position, whether it could include in those institutions. Therefore, it cannot just be like to place the village as an alternative institution for dispute resolution in accordance with provision because the village is specifically regulated in the Village Law.

Furthermore, did not mention the term Alternative Dispute Resolution, but merelymediation. Based on Article 1 Paragraph 1, the meaning of mediation is stated as follows: "Mediation is a method of alternative dispute resolution through the negotiation process to obtain an agreement from the Parties assisted by the Mediator." In material terms, the understanding of mediation as part of an alternative dispute resolution, which is without litigation. In general, mediation usually handles civil aspects, although it might be possible to handle criminal aspects ${ }^{29}$. According to Article 1 paragraph 2, the meaning of mediator is stated as below:

"Judges or other parties who have Mediator Certificates as neutral parties who assist the Parties in the negotiation process to find various possibilities for alternative dispute resolution without using the ways to cut off or imposing a settlement."

Is it possible for a village head to call a mediator based on his authority to settle the conflict in a village society? Positioning the village head as a mediator cannot just refer to the clause of Article 1 Paragraph 3 Supreme Court Regulation (PERMA) No. 1 of 2016, which stated that non-judge mediator must have certified mediator issued by the Supreme Court or other institutions that have been accredited by the Supreme Court. Based on this, the village head cannot immediately act as a mediator.

The understanding of mediator is entirely various, but in general, the mediator is better understood as a Third Party whose duty is only to help parties resolve their problems without having the authority to make decisions, in other words, the mediator is a facilitator who is expected to help the parties reach agreement ${ }^{30}$.

Various understanding of mediator above have three classifications: ${ }^{31}$

1. Social Network Mediator

2. Authoritative Mediator

3. Independent Mediator

Based on those classifications, the village head is included as a trustworthy mediator, so he is obliged to help his people to solve their problems fairly and equally. The

29 Taufiq, M., et. al. (2017). "Mediasi Sebagai Penguatan Kearifan Lokal Banyumas Dalam Penyelesaian Perkara Pidana". Media Hukum, 24(2), 137-146. https:/ / doi.org/10.18196/jmh.2017.0089.137-146

30 Hanifah, M. (2016). "Kajian Yuridis: Mediasi Sebagai Alternatif Penyelesaian Sengketa Perdata di Pengadilan". ADHAPER: Jurnal Hukum Acara Perdata, 2(1). Retrieved from https://jhaper.org/index.php/JHAPER/article/view/21

31 Pusat Mediasi Indonesia Universitas Gajah Mada. (n.d.). Modul Pendidikan \& Pelatihan Mediator Bersertifikat. Yogyakarta. 
village head which usually being a respected figure in the society has a strong position, so it is very effective in carrying out his role as a mediator ${ }^{32}$.

The village's position has been strengthened by Law No. 6 of 2014, which gives vast authority to the village; also, the village head can establish an alternative dispute resolution institution that accommodates the jurisdiction of the village head in terms of settling society conflicts in the village.

A mediator shall has a certificate as stated in PERMA No. 1 of 2016 and training is required to obtain mediator certification. It is interesting to see that the output of successful mediation is the creation of a Peace Agreement. In the provisions of Article 1, paragraph 9 stated:

"The Peace Agreement is an agreement on the results of the Mediation in the form of a document that contains clauses for alternative dispute resolution which signed by the Parties and Mediators."

The clauses raise a question, whether the "Peace Agreement" made and signed by the parties and the village head has legitimacy. The term "Peace Agreement" consists of two words; "Agreement" and "Peace." Based on searching using KBBI Online, the term "Agreement" refers to a matter of agreement or consensus, so in this case, the use of this term relates normatively to the form of agreement between the parties. Meanwhile, the word "Peace," according to KBBI Online is a stoppage of hostility (conflict, conflict, and so on) or a matter of peace. Generally, the Peace Agreement is one kind of agreement that is based on the principle of freedom contract. Referring to this principle, the creation of a Peace Agreement should not only be carried out by certified mediators but from the parties themselves. The clause in PERMA No. 1 of 2016 itself only regulates mediation within the scope of proceedings in court; it means that it does not regulate mediation widely. Of course, in this case, the use of Regulation No. 1 of 2016 can be negated by the clause in Law No. 6 of 2014, which authorizes and requires the village head to alternative dispute resolution in the village.

The village head in the bureaucratic system is the executive because it is the executor of the law, so the village head does not have the right to examine and judge the parties. However, the village authority to settling society conflicts must also be accommodated. For this reason, mediation by placing the village head as a mediator is the most appropriate effort. The village is the leading destination of the citizen in finding a way out during the conflict, so that village functions are not only limited to aspects of bureaucratic administration, but the purpose of the state in creating peace in the society can be made through the village.

If a question arises, what is the legal legitimacy or legal force of the Peace Agreement made by village mediators rather than a judge mediator or certified mediator? Answering this question, actually in PERMA No. 1 of 2016 has provided opportunities to the public if they want to make a Peace Agreement. Hence, not only Peace Agreements made by certified mediators or judge mediators can be filed and raised into a Peace Deed, but a Peace Agreement made by parties without the assistance of a certified Mediator can be submitted too. It is clearly stipulated in Article 36, Paragraph 1 PERMA No. 1 of 2016, which states:

32 Rahayu, S. L., et. al. (2016). "Penguatan Fungsi Kepala Desa Sebagai Mediator Perselisihan Masyarakat Di Desa". Yustisia Jurnal Hukum, 5(2), 340-360. https:/ / doi.org/10.20961/yustisia.v95i0.2812 
"The Parties with or without the assistance of a certified Mediator who successfully alternative dispute resolutions outside the Court with a Peace Agreement can submit a Peace Agreement to the Court that has the authority to obtain a Peace Deed by filing a claim."

Based on these clauses, the Supreme Court admits that mediation which carried out independently outside the court by the parties or assisted by other parties, e.g., uncertified mediators. Through this clause, the village can recreate peace of society independently by becoming a destination in resolving conflicts; nevertheless, this is an actualization of village sovereignty in the judiciary but with limited rights, only to call, examine, reconcile, and to resolve without the authority to judge and execute.

\section{Conclusions}

After the reformation, the government of Indonesia realized the importance of maintaining and developing the potential of each village, both in the economic and other fields. Things began to change with the legitimation of Law No. 6 of 2014 concerning Village, which gave huge rights and authority to the village. One of the authorities is the position of the village as the organizer of social peace, and the village head is obliged to resolve society disputes in the village. Although the village no longer has a judiciary (due to governmental affairs), the village can develop alternative dispute resolution institutions, and the village head can be the organizer as an intermediary in charge of summoning, examining, mediating, and resolving problems from the parties.

Recommendation ased on the discussion and conclusions above, it is necessary to give some suggestions on the results of this normative research, such as: The Supreme Court needs to improve PERMA No. 1 of 2016 concerning Mediation in the Court where the content fully mentions the Village Head can act as a mediator if the litigant is the people in those villages; The village head needs to be trained in terms of knowledge and abilities in the field of mediation and act as a mediator; Villages begin to form and develop mediation institutions so they can become a forum for rural communities who need assistance in alternative dispute resolution.

\section{References}

\section{Book}

Attamimi, A. H. S. (1990). Peranan Keputusan Presiden Republik Indonesia Dalam Penyelenggaraan Pemerintahan Negara. Universitas Indonesia.

Boechari. (1975). Jayapatra Sekelumit Tentang Pelaksanaan Hukum dalam Masyarakat Jawa Kuno. In Simposium Sejarah Hukum. Bandung: BPHN Kemenkuham.

Eko, S. (2005). Mencari Model Pemerintahan dan Otonomi Desa. In R Widodo Triputro dan Supardal (Ed.), Pembaharuan Otonomi Daerah. Yogyakarta: Program Studi Ilmu Pemerintahan STPMD “APMD” dan APMD Press Yogyakarta.

Hadikusuma, H. (1981). Hukum Tatanegara Adat. Jakarta: Alumni.

Hatta, M. (1966). Demokrasi Kita. Djakarta: PT Pusaka Antara.

Kusumaatmadja, M. (2006). Konsep-Konsep Hukum dalam Pembangunan; Kumpulan Karya 
Tulisan Prof. Dr. Mochtar Kusumaatmadja, S.H.,LL.M ((Ed.). Otje Salman dan Eddy Damian, Ed.). Bandung: PT Alumni.

Mahkamah Agung Republik Indonesia. (2010). Cetak Biru Pembaharuan Pengadian 20102035. Retrieved from https://www.mahkamahagung.go.id/media/198

Mertokusumo, S. (2011). Sejarah Peradilan dan Perundang-Undangannya Di Indonesia Sejak 1942 dan Apakah Kemanfaatannya Bagi Kita Bangsa Indonesia. Yogyakarta: Universitas Atma Jaya Yogyakarta.

Pusat Mediasi Indonesia Universitas Gajah Mada. (n.d.). Modul Pendidikan E Pelatihan Mediator Bersertifikat. Yogyakarta.

Raharjo, S. (2011). Peradaban Jawa: Dari Mataram Kuno sampai Majapahit Akhir (Cet II). Jakarta: Komunitas Bambu.

Wignjosoebroto, S. (2014). Desentralisasi dalam Tata Pemerintahan Kolonial HindiaBelanda: Kebijakan dan Upaya Sepanjang Babak Akhir Kekuasaan Kolonial di Indonesia 1900-1940. Malang: Banyumedia.

Yamin, M. (1962). Tatanegara Madjapahit (Parwa III). Djakarta: Jajasan Prapantja.

\section{Article Journal}

Alia, M. I. (2017). “Jaminan Konstitusionalitas Hak Asal Usul Masyarakat Hukum Adat di Sumatera Barat. Lex Journal: Kajian Hukum \& Keadilan, 1(2), 1-25. https://doi.org/10.25139/lex.v1i2.550

Basuki, U. (2017). “Desa Mawa Cara Negara Mawa Tata : Dinamika Pengaturan Desa Dalam Sistem". Al Mazahib, 5, 321-344. Retrieved from http://ejournal.uinsuka.ac.id/syariah/almazahib/article/view/1424

Wantu, F.M.. (2013). “Kendala hakim dalam menciptakan kepastian hukum, keadilan, dan kemanfaatan di peradilan perdata". Mimbar Hukum - Fakultas Hukum Universitas Gadjah Mada, 25(2), 205-218.

Fitriati. (2017). “Karakteristik Penyelesaian Tindak Pidana Secara Informal Melalui Peradilan Adat". Media Hukum, 24(2), 164-171. https://doi.org/10.18196/jmh.2017.0092.164-171

Hanifah, M. (2016). “Kajian Yuridis: Mediasi Sebagai Alternatif Penyelesaian Sengketa Perdata di Pengadilan". ADHAPER : Jurnal Hukum Acara Perdata, 2(1). Retrieved from https://jhaper.org/index.php/JHAPER/article/view/21

Rahayu, S. L., et. al. (2016). “Penguatan Fungsi Kepala Desa Sebagai Mediator Perselisihan Masyarakat Di Desa". Yustisia Jurnal Hukum, 5(2), 340-360. https://doi.org/10.20961/yustisia.v95i0.2812

Syamsu, S. (2008). "Memahami Perkembangan Desa di Indonesia". Jurnal Government Ilmu Pemerintahan, $I(\mathrm{I})$.

Taufiq, M. et. al. (2017). “Mediasi Sebagai Penguatan Kearifan Lokal Banyumas Dalam Penyelesaian Perkara Pidana". Media Hukum, 24(2), 137-146. https://doi.org/10.18196/jmh.2017.0089.137-146 


\section{Internet}

Badan Pusat Statistik. (n.d.). Jumlah Desa/Kelurahan Menurut Provinsi dan Topografi Wilayah, 2003-2018. Retrieved from www.bps.go.id website: https://www.bps.go.id/linkTableDinamis/view/id/907

Matanasi, P. (2017). Asal-Usul Rukun Tetangga. Retrieved from tirto website: https://tirto.id/asal-usul-rukun-tetangga-cBhG 